\title{
128 異所性心房性頻拍に対する外科治療
}

\author{
金沢大学 第 1 外科

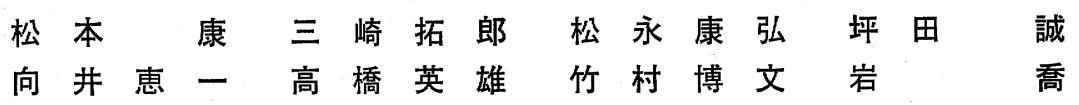

異所性心房性頻拍症は薬剂抵抗性であり，しかもペー スメーカーおよび直流通電は無効である. 頻拍により心 不全を呈する重症例では手術沿療が考えられてきたが, 従来の方法は房室ブロック作成術であり問題点む多い. 今回われわれは，異所性心房性頻拍症に対して，電気生 理学的検査に基づいて異所性中枢部を決定し, 根治的直 達手術を行い良好な結果を得たので報告する.

\section{対象と方法}

対象は当科で異所性心房性頻拍症に対して手術治療を 行った 5 例である. 年齡は 16 歳から 54 歳, 平均 26 歳であった. 5 例は $2 \sim 7$ 年間にわたって, 持続性の頻 拍を有しており, 多種の抗不整脈剂による薬物療法を受 けていた。 また，直流通電む効果がなく全例で心拡大な ぞの心不全症状の合併を認めた（表 1 ).

術前検査として心電図, 体表面電位図, 電気生理学的 検査, カテーテル心内膜マッピングを施行し, 術中検査 として心外膜マッピング, paced mapping, 心内膜マッ ピングを施行していずれも異所性中枢による心房性頻拍 と診断した。

電気生理学的検索では異所性中枢の存在をしめす最早 期興奮部位は 2 例で左心耳, 1 例で右心耳, 1 例で心房 中隔, 1 例で左房後壁と両心房内に広範に分布してい た.

手術術式は異所性中枢が左心耳に存在した 2 例に対し て心筋切除亡冷凍凝固を併用し, 右心耳に存在した 1 例

表 1 症例の臨床像および使用薬剤

\begin{tabular}{ccccll}
\hline Case & Age & Sex & Heart rate & \multicolumn{1}{c}{ Symptom } & Medication \\
\hline 1 & 19 & M & 180 & CHF & V, P \\
2 & 18 & M & 100 & Chest discomfort & V, D, P, Dg \\
3 & 54 & F & 135 & CHF & V,P, Dg \\
4 & 23 & M & 175 & CHF, Syncope & V, A, PA \\
5 & 16 & M & 164 & CHF & V, D, P, Dg \\
\hline
\end{tabular}

CHF : congestive heart failure, $\mathrm{V}$ : verapamil,

$\mathrm{P}$ : propranolol, D : disopyramide, Dg: digoxin, $\mathrm{PA}$ : procaine amide
表 2 最早期興奮部位および手術

\begin{tabular}{cclc}
\hline Case & Location of focus & Procedure & CPB $^{*}$ \\
\hline 1 & Left appendage & Excision+Cryo & - \\
2 & Left appendage & Excision+Cryo & - \\
3 & Right appendage & Excision & - \\
4 & Atrial septum & Excision+Cryo & + \\
5 & LA post. wall & Cryo & - \\
\hline
\end{tabular}

CPB* : cardiopulmonary bypass

に対しては切除単独を行い，心房中隔に存在した 1 例に 対しては心房中隔切除とパッチ関鎖および冷凍凝固，左 房後壁に存在した 1 例に対しては冷凍凝固単独を施行し た. また心耳に存在した 3 例之左房後壁の 1 例では人工 心肺の使用なしに手術を行いえた（表 2 ）。

\section{結果}

異所性中枢の存在部位が心耳, 心房中隔, 左房後壁の 3 型に大別されるため，それぞれにつき術中マッピング と手術法をシェーマに示す。

まず異所性中枢が心耳に存在した例を示す（図 1 上 段)．心外膜マッピングは術前検査とよく一致していた. 手術時には人工心肺を使用せず，右心耳を基部より切除 した。これによりただちに頻拍は消失し同調律となっ た. 左心耳に異所性中枢の存在した 2 例でも同様に心耳 の切除を行い冷凍凝固を追加した.

ついで異所性中枢が心房中隔に存在した例を示す（四 1 中段),手術は人工心肺が不可欠であり心拍動下に，右 房切開により中隔の心内膜マッピングを行った．最早期 興奮部位は卵円嘸下縁にあり，乙の部分の冷凍凝固を行 った．しかし心房中隔の別の部位を中枢とする頻拍が出 現したため，心房中隔を切除しパッチ閉鎖を行った．

最後に異所性中枢が左房後壁に存在した例を示す（図 1 下段).術中心外膜マッピングでは下大静脈付近の左房 後壁に最早期興奮部位が存在した. 手術は人工心肺を使 用せず，心臟を脱転し，最早期興奮部位の冷凍凝固を行 った，心筋切除は術野が狭く行いえなかった。

手術治療により 4 例で頻拍は完全に消失した，1例で 
(appendage)
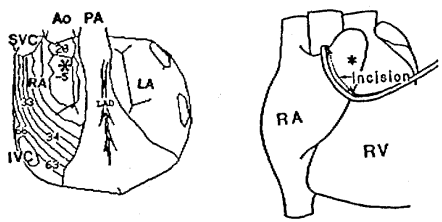

(IAS)
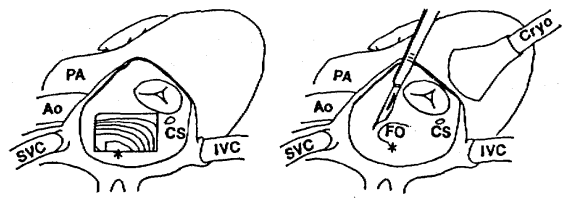

(LA post. wall)
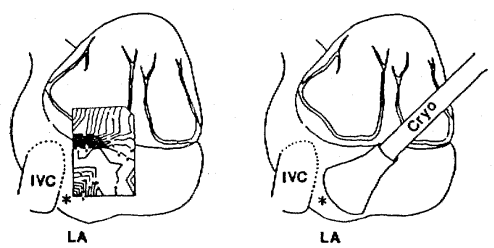

図 1 異所性中枢存在部位別の心外膜マッピングと手術

は術前と異なる部位からの頻拍を認めたが，頻拍の頻 度, 心拍数の減少を得, 症状は軽快した。なお術後全例 において抗不整脈剤の使用を中止することが可能であ り，心不全も全例において改善がみられた。

\section{考案}

心房性頻拍においては発作性のむのは回帰性機序であ り，慢性型（持続性）のものは異所性中枢によると考え られている1'. 回㷌性機序によるものはペーシング療法 や薬物療法によく反応するが異所性中枢によるものはい ずれに対しても抵抗性であり直流通電も無効である2 今回検討を行った 5 例に関しても，いずれも薬物治療や 直流通電が無効であり，長期間にわたる頻拍の既往を有 し，ほとんどが心不全症状を有する症例であった。

異所性中枢部位の決定が外科治療を行う際には必須で あり, 術前検査のうちで最む確実かつ有用であったのは 電気生理学的検査時のカテーテル電極による心内膜マッ
ピング 3)であり全例異所性中枢の部位推定が可能であっ た.さらに，同時に施行した電気刺激検査により頻拍機 序の解析屯可能であった．術中の心房心外膜マッピング 法4)は最古確実な診断法であり，後に検索した病理学的 異常部位とも一致を示した。

難治性上室性頻拍に対して His 束切断十ペースメー カー植込みが報告されているが5)，異所性心房性頻拍に 対する直接的な外科治療は 1973 年に Coumel ら ら $^{6}$ が発 表して以来報告例は少ない. 手術方法としては切除不 能部位に存在する異所性中枢の周辺部を電気凝固した Coumel の 1 例と左上肺静脈流入部周辺に存在した異所 性中枢部を左房切開により, 電気的に隔離した Ander son ら の 1 例のほかは，われわれが行ったように異所 性中枢部の切除冷凍凝固の単独もしくは併用であり ${ }^{82}$, この点からも直達手術の有用性が示唆される。

本頻指症は一般に致死的でないと考えられているた め，薬物治療が無効であっても漫然と抗不整脈楽が長期 間投与されたり，放置されている症例が多かった9). し かし，心不全を合併している患者にさらに心機能を低下 させる抗不整脈剂の使用や若年者における抗不整脈薬の 長期使用の問題，患者本人の精神的肉体的苦痛などの問 題も存在している.

今回の臨床電気生理学に基づく直達手術により, 人工 心肺の使用を最小限にとどめながら，きわめて安全かつ 簡単に両心房および中隔を起源とする, 異所性心房性頻 拍症全例で頻拍の消失あるいは軽減が得られた．乙のこ とは積極的な直達手術の有效性を示すものである.

異所性中枢が両心房のいかなる場所飞存在しても，刺 激部位の局在を確実にし，その部位の切除，冷凍凝固の いずれかによって根治可能であり ${ }^{10)}$, 今後の手術適応症 例の増加が期待される.

文 献 1) Josephson, M. E. et al.: Ann. Intern. Med. 87:346, 1977 2) Scheinman, M. M. et al. : Circulation $50: 266,1974 . \quad 3)$ Svenson, R. H. et al.: Circulation 52 : $552,1975.4)$ 岩 喬ほ力：日胸外会誌 28: 361, 1980.5 ) Sealy, W.C. et al.: Ann. Thorac. Surg. $32: 429,1981$. 6) Coumel, P. et al.: Ann. Cardiol. Angeiol. 22 : 189, 1973. 7) Anderson, K. P. et al. : Am. J. Cardiol. 49 : 869, 1982. 8) 岩 喬ほ加: 内科 $51: 245,1983.9)$ 岩 喬ほ加:日 本臨床 43:2304, 1985 . 10) 松永康弘ほか：心臟 19:89, 1987. 